\title{
Process Improvements Using the NCMS Electrical Testing Methodology
}

Federal Manufacturing \& Technologies
S. E. Goldammer and
D. R. Tucker

KCP-613-5927
PECEIVED

\author{
JUL 141997
}

OSTI

Published June 1997

Final Report

S. E. Goldammer, Project Leader

DISTRBOTION OF THIS DOCUMENT IS UNLMITED

Approved for public release; distribution is unlimited.
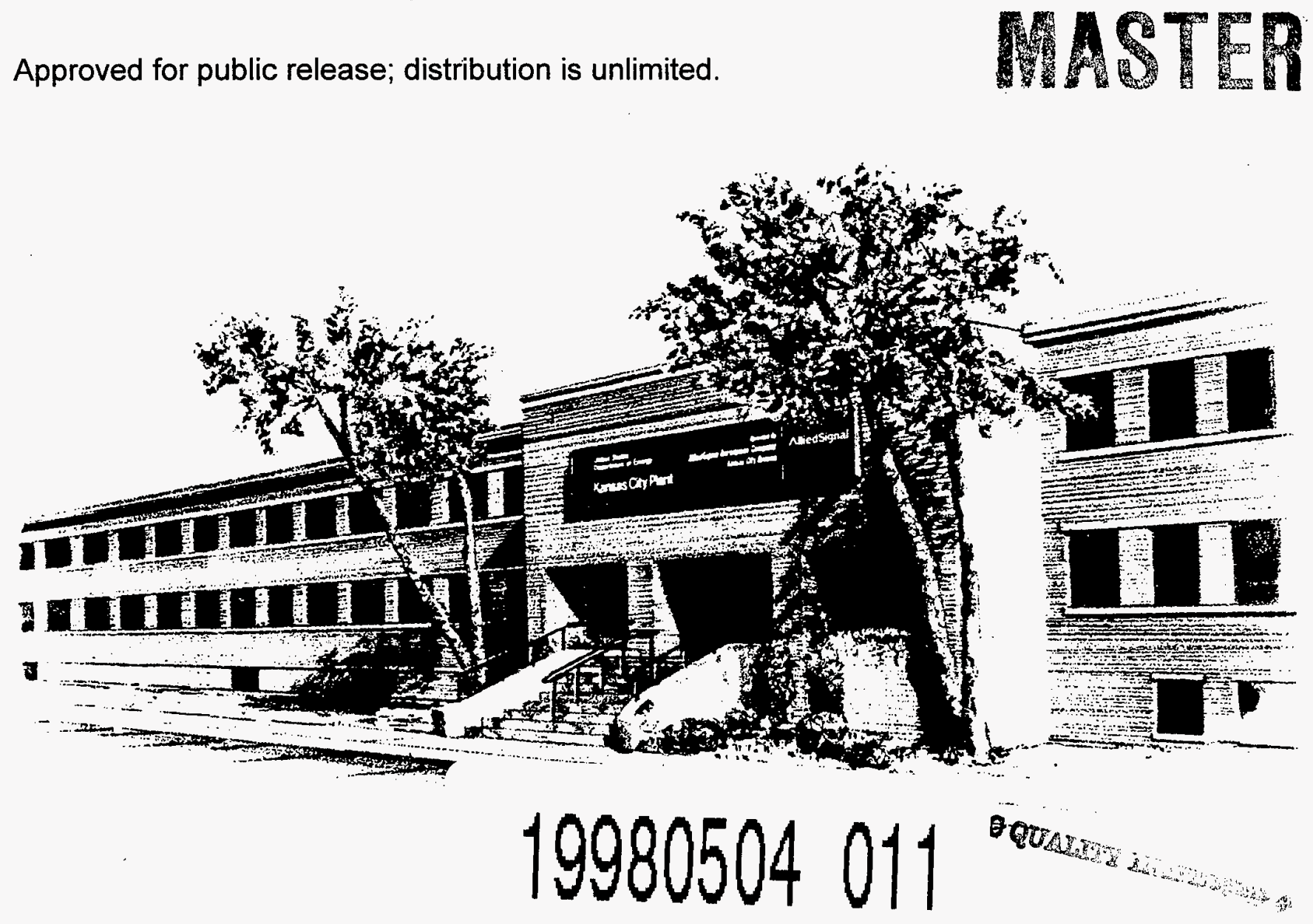

Prepared Under Contract Number DE-ACO4-76-DP00613 for the 


\section{DISCLAIMER}

This report was prepared as an account of work sponsored by an agency of the United States Government. Neither the United States Government nor any agency thereof, nor any of their employees, makes any warranty, express or implied, or assumes any legal liability or responsibility for the accuracy, completeness, or usefulness of any information, apparatus, product, or process disclosed, or represents that its use would not infringe privately owned rights. The views and opinions of authors expressed herein do not necessarily state or reflect those of the United States Government or any agency thereof.

All data prepared, analyzed and presented has been developed in a specific context of work and was prepared for internal evaluation and use pursuant to that work authorized under the referenced contract. Reference herein to any specific commercial product, process or service by trade name, trademark, manufacturer, or otherwise, does not necessarily constitute or imply its endorsement, recommendation, or favoring by the United States Government, any agency thereof or AlliedSignal Inc.

Printed in the United States of America.

This report has been reproduced from the best available copy.

Available to DOE and DOE contractors from the Office of Scientific and Technical Information, P. O. Box 62, Oak Ridge, Tennessee 37831; prices available from (615) 576-8401, FTS 626-8401.

Available to the public from the National Technical Information Service, U. S. Department of Commerce, 5285 Port Royal Rd., Springfield, Virginia 22161.

A prime contractor with the United States Department of Energy under Contract Number DE-ACO4-76-DP00613.
AlliedSignal Inc.

Federal Manufacturing \& Technologies

P. O. Box 419159

Kansas City, Missouri

64141-6159 
Approved for public release; distribution is unlimited.

\title{
PROCESS IMPROVEMENTS USING THE NCMS ELECTRICAL TESTING METHODOLOGY
}

\author{
S. E. Goldammer and \\ D. R. Tucker
}

Published June 1997

Final Report

S. E. Goldammer, Project Leader 


\section{CONTENTS}

Section

Page

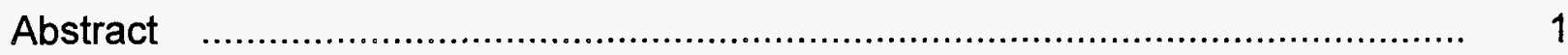

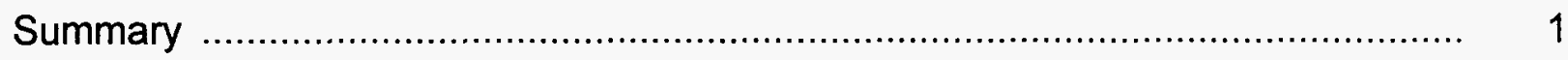

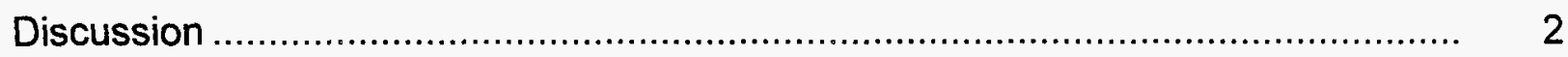

Scope and Purpose

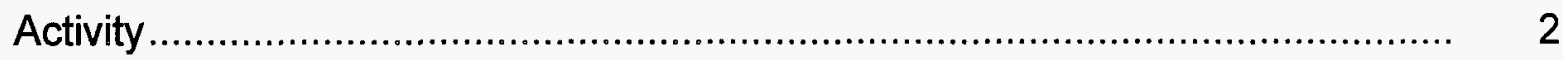

NCMS Imaging Team ...................................................................... 2

Baseline of DuPont's 4615 Photoresist on 12 by 12 Inch Panels ................. 4

Preliminary Evaluation of DuPont's 9015 Photoresist on

18 by 24 Inch Panels .......................................................................... 5

Baseline of DuPont's 4615 Photoresist on 18 by 24 Inch Panels ................ 6

Qualification of DuPont's 9015 Dry Film Photoresist for Production Use....... 8

Baselining Pattern Plate .............................................................. 11

Etcher Qualification..................................................................... 13

Final Process Benchmarking Comparison .............................................. 17

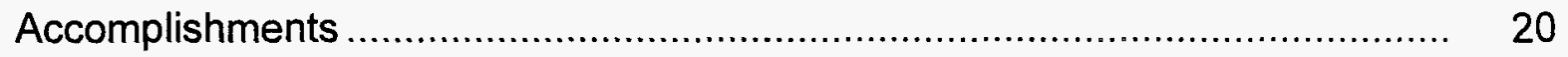

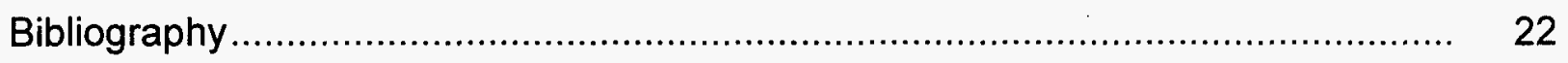

Appendix. FM\&T Print and Etch Processing Sequence and Parameters

Used for Etch Equipment Qualification 


\section{TABLES}

Number

Page

1 Conductor Yield vs. Nominal Conductor Width, TM1 and TM2 Sides, 12 by 12 inch Panels, DuPont 4615 Photoresist

2 Conductor Yield vs. Nominal Conductor Width, TM1 and TM2 Sides, 18 by 24 inch Panels, DuPont 9015 Photoresist

3 Conductor Yield vs. Nominal Conductor Width, TM1 and TM2 Sides, 18 by 24 inch Panels, DuPont 4615 Photoresist

4a Conductor Yield vs. Nominal Conductor Width, TM1 and TM2 Sides, Etched 7/94, Group 1

4b Conductor Yield vs. Nominal Conductor Width, TM1 and TM2 Sides, Etched 7/94, Group 2

4c Conductor Yield vs. Nominal Conductor Width, TM1 and TM2 Sides, Etched 7/94, Group 3

4d Conductor Yield vs. Nominal Conductor Width, TM1 and TM2 Sides, Etched 7/94, Group 4

4e Conductor Yield vs. Nominal Conductor Width, TM1 and TM2 Sides, Etched 7/94, Group 5

$4 f$ Conductor Yield vs. Nominal Conductor Width, TM1 and TM2 Sides, Etched 7/94, Group 6

5 DuPont 9015 Photoresist Data

6 Conductor Yield vs. Nominal Conductor Width, TM1 and TM2 Sides,

Day 1

7 Conductor Yield vs. Nominal Conductor Width, TM1 and TM2 Sides,

Day 2

8a Conductor Yield vs. Nominal Conductor Width, TM1 and TM2 Sides, Day 1, Atotech Etched.

8b Conductor Yield vs. Nominal Conductor Width, TM1 and TM2 Sides, Day 2, Atotech Etched. 
8c Conductor Yield vs. Nominal Conductor Width, TM1 and TM2 Sides, Day 3, Atotech Etched

8d Conductor Yield vs. Nominal Conductor Width, TM1 and TM2 Sides, Day 1 - 3, Atotech Etched

9a Conductor Yield vs. Nominal Conductor Width, TM1 and TM2 Sides, Day 1, Chemcut Etched.

9b Conductor Yield vs. Nominal Conductor Width, TM1 and TM2 Sides, Day 2, Chemcut Etched.

9c Conductor Yield vs. Nominal Conductor Width, TM1 and TM2 Sides, Day 3, Chemcut Etched.

9d Conductor Yield vs. Nominal Conductor Width, TM1 and TM2 Sides, Day 1 - 3, Chemcut Etched

10 Total Accumulated Data Comparing Atotech and Chemcut Runs

11 Conductor Yield vs. Nominal Conductor Width, TM1 and TM2 Sides, DuPont 4615, Alkaline Etched on 2/96, Tested by Conductor Analysis Technologies Inc.

12 Conductor Yield vs. Nominal Conductor Width, TM1 and TM2 Sides, DuPont 9015, Alkaline Etched on 2/96, Tested by Conductor Analysis Technologies Inc.

13 Conductor Yield vs. Nominal Conductor Width, TM1 and TM2 Sides, DuPont 4615 Photoresist, Etched 2/96, Tested by Texas Instruments ...

14. Conductor Yield vs. Nominal Conductor Width, TM1 and TM2 Sides, DuPont 9015 Photoresist, Etched 2/96, Tested by Texas Instruments ...

15 Uniformity Multipitch Pattern Results

16 Multipitch 2-12 Pattern Results

A-1 Wet Blast and Chemical Clean .......................................................... 23

A-2 Laminate Resist........................................................................... 23

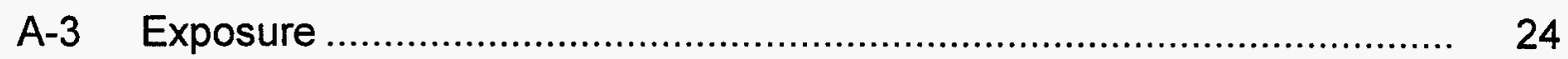

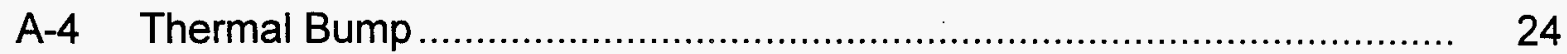


A-5 Developing

A-6 Etching

A-7 Stripping Photoresist
24

25

25

V 


\section{ABSTRACT}

The conductor analysis electrical testing method uses the artwork patterns and equipment developed by the National Center for Manufacturing Sciences (NCMS) Printed Wiring Board Imaging Team. These patterns and electrical test methods are used to evaluate new or improve existing printed wiring board processes.

\section{SUMMARY}

AlliedSignal Federal Manufacturing \& Technologies (FM\&T) was involved with the last two years of this five-year team commitment. The accomplishments of the FM\&T/NCMS involvement can be summarized in the following three categories:

\section{Baselining}

FM\&T imaging capability was baselined. Real-time improvements were seen between panels processed in 1994 as compared to panels processed in 1996 using the 5-8 uniformity multipitch pattern and tested by Conductor Analysis Technologies Inc. (CAT Inc.). However, no noticeable improvement can be seen in comparing the panels processed in 1994 and panels processed in 1996 using the multipitch 2-12 pattern and tested by Texas Instruments, Austin, TX.

\section{Process Qualification}

The conductor analysis electrical testing method was used to evaluate and qualify a new dry film photoresist and a new alkaline etch system, thereby reducing both time and expense. Prior to the availability of this tool, the patterns were measured manually; numerous cross sections and scanning electron microscope (SEM) examinations were required to completely qualify imaging materials and equipment. By using the conductor analysis electrical testing method, labor was reduced by approximately $80 \%$. Qualification time was estimated to have been reduced by $50 \%$.

\section{Continuous Improvement Assessment}

Based on the labor and qualification time reduction experienced with conductor analysis electrical testing, FM\&T ordered electrical test equipment from CAT Inc. for process verification, characterization, and qualification. The tester was delivered in mid-1996. 


\section{DISCUSSION}

\section{SCOPE AND PURPOSE}

The purpose of this report is to document the objectives and accomplishments of the AlliedSignal Federal Manufacturing \& Technologies/Kansas City (FM\&T) involvement in the National Center for Manufacturing Sciences (NCMS) Printed Wiring Board Imaging Team. This report documents the work done by FM\&T during only the period of May 1994 through April 1996. The emphasis of the involvement was to improve the imaging capability of the printed wiring board (PWB) manufacturing facility using the common artwork patterns developed by the NCMS Imaging Team. These patterns were designed to produce a series of electrical circuits that could be quickly and easily tested on special test equipment also developed by the NCMS members. This method of evaluating pattern characteristics will be referred to in this report as conductor analysis electrical testing.

\section{ACTIVITY}

\section{NCMS Imaging Team}

\section{Background}

The NCMS Imaging Team was formed in the Spring of 1991 . The NCMS Imaging Team charter was a five-year commitment to improve large area (18 by 24 inch), fine line, high density conductor manufacturing capability. Fine lines were defined as conductors and spaces less than 5 mils ( 0.005 inch) wide. A five-mil line and an adjacent five-mil space is referred to as a 10-mil pitch (line width plus space width).

Within the first few years, the NCMS Imaging Team developed and used a conductor analysis electrical testing methodology to characterize, track, and optimize photoimaging processes. This methodology used a specially designed electrical test system to measure the electrical properties of conductors that had been imaged with specially designed artwork. The artwork, in conjunction with data from the electrical tester, was referred to as a "communication vehicle." The artwork consisted of multipitch serpentine patterns with a variety of conductor widths separated by a space. The space widths were equal to the average width of its two adjacent conductors.

The electrical testing methodology can be used to measure the thickness of copper conductors, conductor widths, and conductor yields by measuring the 
number defects (shorts and open circuits). Defects are reported as defects per million inches (DEMI) of conductor length.

AlliedSignal, Commercial Aviation Systems (CAS), Olathe, Kansas, joined the NCMS in 1993 but could not continue their support after a decision was made to close their PWB manufacturing facility. FM\&T was encouraged to participate by Sandia National Laboratory/New Mexico and began attending meetings in May 1994. Even though FM\&T joined the imaging team three years after the project began (total FM\&T participation time was two years), the NCMS Imaging Team was very flexible and supportive of the FM\&T efforts.

FM\&T entered the NCMS project (as did the other companies) with the following questions in mind:

- How do we compare with industry?

- What is the industry standard?

- Where is industry headed?

- What problems are common to industry?

- What problems are unique to FM\&T?

The NCMS Imaging Team used the communication vehicle to answer some of these questions.

\section{Baselining}

The first step in improving any process is to establish the current capability of the process. This current capability is then used as the starting point or "baseline" for measuring progress. The NCMS Imaging Team members benchmarked the photoimaging process by comparing their own individual baselining data.

\section{FM\&T Evaluations}

Although 18 by 24 inch panels were generally used for baselining, FM\&T began baselining with 12 by 12 inch panels because that was their standard production panel size. Later, 18 by 24 inch panels were used. All FM\&T panels were covered on both sides with 1 ounce copper ( 0.0014 inch thick copper).

The negative artwork used for print and etch patterning included the multipitch (MP) 2-12, the Uniformity Multipitch (UMP) 3-6, and the UMP 5-8. The positive artwork used for pattern plating was the MP 2-12. 
The following is a chronological record of seven evaluations that were done using the conductor analysis testing.

\section{Baseline of DuPont's 4615 Photoresist on 12 by 12 Inch Panels}

The first opportunity for FM\&T to baseline standard production product by using the electrical tester was in March 1994 at the National Electronics Packaging and Production Conference (NEPCON) in Anaheim, California, where NCMS showcased the conductor analysis electrical tester to demonstrate the tester's capability.

The print and etch pattern used was the UMP 5-8. DuPont's 4615 dry film photoresist was used in the photoimaging process. The standard processing parameters for the 4615 resist were as follows:

- Copper cleaning (prior to photoresist lamination) -- conveyorized alkaline spray followed by copper microetch (see Appendix).

- Dry film lamination $--105^{\circ} \mathrm{C}$, exit board temperature (EBT) $145^{\circ} \mathrm{F}, 0.8 \mathrm{mpm}$.

- Expose -- Stouffer step 9.

- Develop -- conveyorized spray of $1 \%$ sodium carbonate followed by deionized (DI) water rinse.

- Etch -- ammoniacal copper chloride.

- Strip -- conveyorized spray of $3 \%$ potassium hydroxide followed by DI water rinse.

- Copper cleaning (same as first).

The results of this baseline process are shown in Table 1.

Table 1. Conductor Yield vs. Nominal

Conductor Width, TM1 and TM2

Sides, 12 by 12 Inch Panels, DuPont 4615 Photoresist

\begin{tabular}{|c|c|c|}
\hline $\begin{array}{c}\text { Artwork } \\
\text { Feature } \\
\text { Size (mils) }\end{array}$ & $\begin{array}{c}\text { Conductor } \\
\text { Yield (\%) }\end{array}$ & DEMIS \\
\hline 5 & 95.06 & 4066 \\
\hline 6 & 94.94 & 4218 \\
\hline 7 & 96.31 & 3081 \\
\hline 8 & 97.62 & 1989 \\
\hline
\end{tabular}

DEMIS = Defects per Million Inches of Conductor 
Results of 12 by 12 inch panel baseline:

- Shorts were reported as the biggest contributor to defects (DEMIS).

- More shorts were found on the bottom of the panel than on the top.

- FM\&T was about average when compared to industry but below average when compared to other NCMS Imaging Team members.

Accomplishments of 12 by 12 inch panel baseline:

- First baseline of print and etch process completed.

\section{Preliminary Evaluation of DuPont's 9015 Photoresist on 18 by 24 Inch Panels}

This work was done to evaluate DuPont's 9015 dry film photoresist on 18 by 24 inch panels. Artwork print and etch pattern MP 2-12 was obtained from AlliedSignal CAS in Olathe, Kansas.

Processing parameters for the 9015 resist were:

- Copper cleaning (prior to photoresist lamination) -- conveyorized alkaline spray followed by copper microetch

- Dry film lamination $--105^{\circ} \mathrm{C}$, exit board temperature (EBT) $145^{\circ} \mathrm{F}, 0.8 \mathrm{mpm}$.

- Expose -- Stouffer step 9.

- Develop -- conveyorized spray of $1 \%$ sodium carbonate followed by deionized (DI) water rinse.

- Etch -- ammoniacal copper chloride.

- Strip -- conveyorized spray of $3 \%$ potassium hydroxide followed by DI water rinse.

- Copper cleaning (same as first).

Panels were tested with an NCMS conductor analysis electrical tester at Texas Instruments in Austin, TX.

Data from this test is shown in Table 2.

Results of 18 by 24 inch preliminary evaluation:

- FM\&T capability was about average for Industry but below average compared to other members of the NCMS Imaging Team.

- Total DEMIS were 36497.

- No 2 or 3 mil lines were able to be tested.

- FM\&T was not yielding 2 or 3 mil lines, as were the rest of the Imaging Team members. 
Table 2. Conductor Yield vs. Nominal Conductor Width, TM1 and TM2 Sides, 18 by 24 inch Panels, DuPont 9015 Photoresist

\begin{tabular}{|c|c|c|}
\hline $\begin{array}{c}\text { Artwork } \\
\text { Feature } \\
\text { Size (mils) }\end{array}$ & $\begin{array}{c}\text { Conductor } \\
\text { Yield (\%) }\end{array}$ & DEMIS \\
\hline 2 & 0.00 & --- \\
\hline 3 & 0.00 & ---- \\
\hline 4 & 16.50 & 22171 \\
\hline 5 & 57.50 & 6797 \\
\hline 6 & 80.75 & 2622 \\
\hline 7 & 91.25 & 1121 \\
\hline 8 & 92.50 & 953 \\
\hline 9 & 93.75 & 788 \\
\hline 10 & 93.00 & 885 \\
\hline 11 & 93.25 & 852 \\
\hline 12 & 97.50 & 308 \\
\hline
\end{tabular}

DEMIS $=$ Defects per Million Inches of Conductor

Accomplishments of 18 by 24 inch preliminary evaluation:

The results showed that the following processes needed improvement:

- Vacuum draw down during photoresist exposure was pinpointed as the most outstanding area that could be improved for 18 by 24 inch panels.

- Photoresist developing speed was too fast (developing time too short) for 18 by 24 inch panels.

- Etching processes potentially needed adjustments, but the exposing and developing problems made it difficult to pinpoint the specific adjustments at the etcher.

\section{Baseline of DuPont's 4615 Photoresist on 18 by 24 Inch Panels}

This evaluation was done to baseline the print and etch process using DuPont's 4615 photoresist on 18 by 24 inch panels. Artwork pattern MP 2-12 was used. The standard print and etch processes for DuPont's 4615 photoresist were used. The boards were electrically tested at Texas Instruments in Austin, TX. The results are shown in Table 3. 
Table 3. Conductor Yield vs. Nominal Conductor Width, TM1 and TM2

Sides, 18 by 24 Inch Panels, DuPont 4615 Photoresist

\begin{tabular}{|c|c|c|}
\hline $\begin{array}{c}\text { Artwork } \\
\text { Feature } \\
\text { Size (mils) }\end{array}$ & $\begin{array}{c}\text { Conductor } \\
\text { Yield (\%) }\end{array}$ & DEMIS \\
\hline 2 & 0.00 & --- \\
\hline 3 & 0.00 & --- \\
\hline 4 & 0.00 & --- \\
\hline 5 & 17.00 & 21763 \\
\hline 6 & 45.25 & 9724 \\
\hline 7 & 63.75 & 5512 \\
\hline 8 & 78.25 & 2999 \\
\hline 9 & 87.00 & 1701 \\
\hline 10 & 87.75 & 1594 \\
\hline 11 & 92.25 & 983 \\
\hline 12 & 98.25 & 215 \\
\hline
\end{tabular}

DEMIS $=$ Defects per Million Inches of Conductor

Results of 18 by 24 inch baseline:

- FM\&T capability was about average for industry but below average compared to members of the NCMS Imaging Team.

- Total DEMIS 44491.

- No 2, 3, or 4 mil lines were able to be tested.

Accomplishments of 18 by 24 inch baseline:

The results showed that the following processes needed improvement:

- Vacuum draw down during photoresist exposure was pinpointed as the most outstanding area that could be improved for 18 by 24 inch panels.

- Photoresist developing speed was too fast (developing time too short) for 18 by 24 inch panels.

- Etching processes potentially needed adjustments, but the exposing and developing problems made it difficult to pinpoint the specific adjustments at the etcher.

Comparison of 4615 and 9015 results:

- The 9015 did perform slightly better than the 4615 .

- FM\&T was not yielding 2 or 3 mil lines as were the rest of the Imaging Team members. 


\section{Qualification of DuPont's 9015 Dry Film Photoresist for Production Use}

Preliminary work done with DuPont's 9015 dry film photoresist identified exposure and developing as operations that needed improvements. This evaluation used a designed experiment to improve these two areas and qualify DuPont's 9015 photoresist for production use.

Electrical test data was used as the response variable for the designed experiment. Other testing was also done and was documented in another report; however, only the electrical testing data is discussed in this report. This evaluation was done on 12 by 12 inch panels, 1 ounce copper both sides, and electrically tested at Sandia National Laboratories/New Mexico.

Tables $4 a$ through $4 \mathrm{f}$ show each group of testing data. Table 5 combines the data of Tables $4 a-4 f$ to show a side-by-side comparison of the data. Group 1 performed the best.

Table 4a. Conductor Yield vs. Nominal Conductor Width, TM1 and TM2 Sides, Etched 7/94, Group 1

\begin{tabular}{|c|c|c|}
\hline $\begin{array}{c}\text { Artwork } \\
\text { Feature } \\
\text { Size (mils) }\end{array}$ & $\begin{array}{c}\text { Conductor } \\
\text { Yield (\%) }\end{array}$ & DEMIS \\
\hline 5 & 100.00 & 0 \\
\hline 6 & 100.00 & 0 \\
\hline 7 & 100.00 & 0 \\
\hline 8 & 100.00 & 0 \\
\hline
\end{tabular}

DEMIS = Defects per Million Inches of Conductor

Table 4b. Conductor Yield vs. Nominal Conductor Width, TM1 and TM2 Sides, Etched 7/94, Group 2

\begin{tabular}{|c|c|c|}
\hline $\begin{array}{c}\text { Artwork } \\
\text { Feature } \\
\text { Size (mils) }\end{array}$ & $\begin{array}{c}\text { Conductor } \\
\text { Yield (\%) }\end{array}$ & DEMIS \\
\hline 5 & 97.00 & 2446 \\
\hline 6 & 98.00 & 1640 \\
\hline 7 & 99.50 & 411 \\
\hline 8 & 99.50 & 415 \\
\hline
\end{tabular}

DEMIS = Defects per Million Inches of Conductor 
Table 4c. Conductor Yield vs. Nominal Conductor Width, TM1 and TM2 Sides, Etched 7/94, Group 3

\begin{tabular}{|c|c|c|}
\hline $\begin{array}{c}\text { Artwork } \\
\text { Feature } \\
\text { Size (mils) }\end{array}$ & $\begin{array}{c}\text { Conductor } \\
\text { Yield (\%) }\end{array}$ & DEMIS \\
\hline 5 & 99.75 & 201 \\
\hline 6 & 99.50 & 407 \\
\hline 7 & 99.50 & 411 \\
\hline 8 & 99.50 & 415 \\
\hline
\end{tabular}

DEMIS $=$ Defects per Million Inches of Conductor

Table 4d. Conductor Yield vs. Nominal Conductor Width, TM1 and TM2 Sides, Etched 7/94, Group 4

\begin{tabular}{|c|c|c|}
\hline $\begin{array}{c}\text { Artwork } \\
\text { Feature } \\
\text { Size (mils) }\end{array}$ & $\begin{array}{c}\text { Conductor } \\
\text { Yield (\%) }\end{array}$ & DEMIS \\
\hline 5 & 99.75 & 201 \\
\hline 6 & 99.75 & 203 \\
\hline 7 & 99.50 & 411 \\
\hline 8 & 100.00 & 0 \\
\hline
\end{tabular}

DEMIS $=$ Defects per Million Inches of Conductor

Table 4e. Conductor Yield vs. Nominal Conductor Width, TM1 and TM2 Sides, Etched 7/94, Group 5

\begin{tabular}{|c|c|c|}
\hline $\begin{array}{c}\text { Artwork } \\
\text { Feature } \\
\text { Size (mils) }\end{array}$ & $\begin{array}{c}\text { Conductor } \\
\text { Yield (\%) }\end{array}$ & DEMIS \\
\hline 5 & 99.50 & 403 \\
\hline 6 & 99.25 & 611 \\
\hline 7 & 99.25 & 617 \\
\hline 8 & 99.50 & 415 \\
\hline
\end{tabular}

DEMIS $=$ Defects per Million Inches of Conductor 
Table 4f. Conductor Yield vs. Nominal

Conductor Width, TM1 and TM2

Sides, Etched 7/94, Group 6

\begin{tabular}{|c|c|c|}
\hline $\begin{array}{c}\text { Artwork } \\
\text { Feature } \\
\text { Size (mils) }\end{array}$ & $\begin{array}{c}\text { Conductor } \\
\text { Yield (\%) }\end{array}$ & DEMIS \\
\hline 5 & 99.50 & 403 \\
\hline 6 & 99.25 & 611 \\
\hline 7 & 99.25 & 617 \\
\hline 8 & 99.50 & 415 \\
\hline
\end{tabular}

DEMIS $=$ Defects per Million Inches of Conductor

Table 5. DuPont 9015 Photoresist Data

\begin{tabular}{|c|c|c|c|c|c|c|c|}
\hline $\begin{array}{c}\text { Exposure } \\
\text { Setting }\end{array}$ & $\begin{array}{c}\text { Developing } \\
\text { Speed } \\
\text { (fpm) }\end{array}$ & Group & $\mathbf{5}$ mil & $\mathbf{6}$ mil & $\mathbf{7 ~ m i l}$ & $\mathbf{8} \mathbf{~ m i l}$ & $\begin{array}{c}\text { Total } \\
\text { DEMIS }\end{array}$ \\
\hline 110 & 2.0 & 1 & 100.00 & 100.00 & 100.00 & 100.00 & 0 \\
\hline 80 & 2.0 & 2 & 97 & 98 & 99.5 & 99.5 & 4909 \\
\hline 80 & 2.5 & 3 & 99.75 & 99.5 & 99.5 & 99.5 & 1434 \\
\hline 110 & 2.5 & 4 & 99.75 & 99.75 & 99.5 & 100.0 & 815 \\
\hline 110 & 3.25 & 5 & 99.5 & 99.25 & 99.25 & 99.25 & 2046 \\
\hline 80 & 3.25 & 6 & 99.5 & 99.25 & 99.25 & 99.50 & 2046 \\
\hline
\end{tabular}

Results of DuPont's 9015 for production use:

- The UMP 5-8 pattern showed some discrimination in the parameter values selected, but a finer pattern would probably show more of a difference.

- Higher exposure and increased developing time improved yield.

Accomplishments of DuPont's 9015 for production use:

- The exposure and developing parameters for DuPont's 9015 dry film photoresist were optimized.

- The conductor analysis electrical testing proved to be a valuable tool that is easy to use, and qualification time for process changes was significantly reduced. 


\section{Baselining Pattern Plate}

The MP 2/12 artwork was used for pattern plating baseline. At the time of this evaluation, NCMS did not have a large database on pattern plated product using the test patterns. The artwork was obtained from AlliedSignal CAS in Olathe, Kansas. The material used was 18 by 24 inch panels with one ounce copper on both sides. Since 12 by 12 inch panels were standard at FM\&T, this evaluation somewhat challenged the capability of the normal production. Panels were processed on two separate days to compare the consistency of the results from one day to the next. The results are shown in Tables 6 and 7 .

Following is the processing sequence for pattern plate

- Electroless Copper

- Copper Flash

- Wet Blast

- Chemical Clean

- Hot Roll Laminate

- Expose

- Develop

- Copper/Tin Electroplate

- Photoresist Strip

- Alkaline Etch

- Tin Strip

- Electrical Test

Some specific processing parameters noted were:

- Resist type -- DuPont's 9015

- Hot Roll Laminate -- $105^{\circ} \mathrm{C}, 0.5 \mathrm{mpm}, \mathrm{BET}\left(150-153^{\circ} \mathrm{F}\right)$

Expose - setting 65 (Table 6)

80 (Table 7)

- Develop - conveyor speed $2.00 \mathrm{fpm}$ (Table 6)

$2.25 \mathrm{fpm}$ (Table 7)

- Copper/Tin Electroplate - double preplate clean cycle

Results of pattern plate baseline:

- The 2, 3, and 4 mil plated circuits lifted after photoresist strip.

- Some bridging was seen after photoresist strip.

- FM\&T was at about average capability for industry, but below average compared to members of the NCMS Team.

Accomplishments of pattern plate baseline:

- Baseline for pattern plated product. 
Table 6. Conductor Yield vs. Nominal Conductor Width, TM1 and TM2 Sides, Day 1

\begin{tabular}{|c|c|c|}
\hline $\begin{array}{c}\text { Artwork } \\
\text { Feature } \\
\text { Size (mils) }\end{array}$ & $\begin{array}{c}\text { Conductor } \\
\text { Yield (\%) }\end{array}$ & DEMIS \\
\hline 2 & 0.00 & --- \\
\hline 3 & 0.42 & 67570 \\
\hline 4 & 6.25 & 34116 \\
\hline 5 & 14.17 & 24002 \\
\hline 6 & 37.92 & 11892 \\
\hline 7 & 58.33 & 6599 \\
\hline 8 & 76.67 & 3249 \\
\hline 9 & 81.67 & 2473 \\
\hline 10 & 82.92 & 2285 \\
\hline 11 & 84.17 & 2101 \\
\hline 12 & 91.25 & 1115 \\
\hline
\end{tabular}

DEMIS = Defects per Million Inches of Conductor

Table 7. Conductor Yield vs. Nominal Conductor Width, TM1 and TM2 Sides, Day 2

\begin{tabular}{|c|c|c|}
\hline $\begin{array}{c}\text { Artwork } \\
\text { Feature } \\
\text { Size (mils) }\end{array}$ & $\begin{array}{c}\text { Conductor } \\
\text { Yield (\%) }\end{array}$ & DEMIS \\
\hline 2 & 0.00 & ---- \\
\hline 3 & 0.00 & ---- \\
\hline 4 & 0.00 & --- \\
\hline 5 & 17.00 & 21763 \\
\hline 6 & 45.25 & 9724 \\
\hline 7 & 63.75 & 5512 \\
\hline 8 & 78.25 & 2999 \\
\hline 9 & 87.00 & 1701 \\
\hline 10 & 87.75 & 1594 \\
\hline 11 & 92.25 & 983 \\
\hline 12 & 98.25 & 215 \\
\hline
\end{tabular}

DEMIS $=$ Defects per Million Inches of Conductor 


\section{Etcher Qualification}

The print and etch artwork UMP 3-6 pattern was used to accelerate the production qualification of an Atotech Etcher.

This evaluation compared two conveyorized spraying etching systems. One was a Chemcut 547 series, and the other was a newly purchased Atotech Sigma Series etching system. Both were similar in design and used the same alkaline chemistries. This comparison was done to qualify the Atotech etch system by showing that it was "as good as or better" than the Chemcut 547.

Etch uniformity and variation in conductor paths were compared. Other data was used to determine the parameters for characterization; in this report only the yield data from electrical testing is shown for comparison.

Conductor Analysis Technologies Inc. performed the electrical testing. Panels were etched on three separate days to evaluate comparison between days and variation within days. Tables $8 \mathrm{a}$ through $8 \mathrm{~d}$ display the data from panels etched on the Atotech equipment. Tables $9 a$ through $9 \mathrm{~d}$ display the data from panels etched using the Chemcut equipment. Table 10 is a summary of the activity, directly comparing the Atotech vs. Chemcut. The evaluation was done on 18 by 24 inch panels using DuPont 4615 photoresist.

Table 8a. Conductor Yield vs. Nominal Conductor Width, TM1 and TM2 Sides, Day 1, Atotech Etched

\begin{tabular}{|c|c|c|}
\hline $\begin{array}{c}\text { Artwork } \\
\text { Feature } \\
\text { Size (mils) }\end{array}$ & $\begin{array}{c}\text { Conductor } \\
\text { Yield (\%) }\end{array}$ & DEMIS \\
\hline 3 & 90.99 & 5003 \\
\hline 4 & 97.59 & 1307 \\
\hline 5 & 99.26 & 399 \\
\hline 6 & 99.66 & 185 \\
\hline
\end{tabular}

DEMIS $=$ Defects per Million Inches of Conductor 
Table 8b. Conductor Yield vs. Nominal Conductor Width, TM1 and TM2 Sides, Day 2, Atotech Etched

\begin{tabular}{|c|c|c|}
\hline $\begin{array}{c}\text { Artwork } \\
\text { Feature } \\
\text { Size (mils) }\end{array}$ & $\begin{array}{c}\text { Conductor } \\
\text { Yield (\%) }\end{array}$ & DEMIS \\
\hline 3 & 97.54 & 1322 \\
\hline 4 & 98.90 & 594 \\
\hline 5 & 99.27 & 393 \\
\hline 6 & 99.24 & 413 \\
\hline
\end{tabular}

DEMIS $=$ Defects per Million Inches of Conductor

Table 8c. Conductor Yield vs. Nominal Conductor Width, TM1 and TM2 Sides, Day 3, Atotech Etched

\begin{tabular}{|c|c|c|}
\hline $\begin{array}{c}\text { Artwork } \\
\text { Feature } \\
\text { Size (mils) }\end{array}$ & $\begin{array}{c}\text { Conductor } \\
\text { Yield (\%) }\end{array}$ & DEMIS \\
\hline 3 & 97.59 & 1296 \\
\hline 4 & 98.72 & 688 \\
\hline 5 & 99.12 & 477 \\
\hline 6 & 99.32 & 371 \\
\hline
\end{tabular}

DEMIS $=$ Defects per Million Inches of Conductor

Table 8d. Conductor Yield vs. Nominal Conductor Width, TM1 and TM2 Sides, Day 1 - 3, Atotech Etched

\begin{tabular}{|c|c|c|}
\hline $\begin{array}{c}\text { Artwork } \\
\text { Feature } \\
\text { Size (mils) }\end{array}$ & $\begin{array}{c}\text { Conductor } \\
\text { Yield (\%) }\end{array}$ & DEMIS \\
\hline 3 & 95.30 & 2553 \\
\hline 4 & 98.38 & 871 \\
\hline 5 & 99.22 & 424 \\
\hline 6 & 99.41 & 320 \\
\hline
\end{tabular}

DEMIS = Defects per Million Inches of Conductor 
Table 9a. Conductor Yield vs. Nominal Conductor Width, TM1 and TM2 Sides, Day 1, Chemcut Etched

\begin{tabular}{|c|c|c|}
\hline $\begin{array}{c}\text { Artwork } \\
\text { Feature } \\
\text { Size (mils) }\end{array}$ & $\begin{array}{c}\text { Conductor } \\
\text { Yield (\%) }\end{array}$ & DEMIS \\
\hline 3 & 85.43 & 8350 \\
\hline 4 & 96.08 & 2138 \\
\hline 5 & 98.01 & 1082 \\
\hline 6 & 98.78 & 667 \\
\hline
\end{tabular}

DEMIS $=$ Defects per Million Inches of Conductor

Table 9b. Conductor Yield vs. Nominal Conductor Width, TM1 and TM2 Sides, Day 2, Chemcut Etched

\begin{tabular}{|c|c|c|}
\hline $\begin{array}{c}\text { Artwork } \\
\text { Feature } \\
\text { Size (mils) }\end{array}$ & $\begin{array}{c}\text { Conductor } \\
\text { Yield (\%) }\end{array}$ & DEMIS \\
\hline 3 & 96.31 & 1995 \\
\hline 4 & 98.36 & 885 \\
\hline 5 & 99.15 & 461 \\
\hline 6 & 99.18 & 447 \\
\hline
\end{tabular}

DEMIS $=$ Defects per Million Inches of Conductor

Table 9c. Conductor Yield vs. Nominal Conductor Width, TM1 and TM2 Sides, Day 3, Chemcut Etched

\begin{tabular}{|c|c|c|}
\hline $\begin{array}{c}\text { Artwork } \\
\text { Feature } \\
\text { Size (mils) }\end{array}$ & $\begin{array}{c}\text { Conductor } \\
\text { Yield (\%) }\end{array}$ & DEMIS \\
\hline 3 & 96.82 & 1714 \\
\hline 4 & 98.58 & 765 \\
\hline 5 & 98.89 & 600 \\
\hline 6 & 99.23 & 418 \\
\hline
\end{tabular}

DEMIS $=$ Defects per Million Inches of Conductor 
Table 9d. Conductor Yield vs. Nominal

Conductor Width, TM1 and TM2

Sides, Day 1- 3, Chemcut Etched

\begin{tabular}{|c|c|c|}
\hline $\begin{array}{c}\text { Artwork } \\
\text { Feature } \\
\text { Size (mils) }\end{array}$ & $\begin{array}{c}\text { Conductor } \\
\text { Yield (\%) }\end{array}$ & DEMIS \\
\hline 3 & 92.73 & 4000 \\
\hline 4 & 97.65 & 1272 \\
\hline 5 & 98.67 & 723 \\
\hline 6 & 99.06 & 513 \\
\hline
\end{tabular}

DEMIS $=$ Defects per Million Inches of Conductor

Table 10. Total Data Accumulated Atotech and Chemcut Runs

\begin{tabular}{|l|c|c|c|c|c|}
\hline Day & $\mathbf{3} \mathbf{~ m i l}$ & $\mathbf{4} \mathbf{~ m i l}$ & $\mathbf{5} \mathbf{~ m i l ~}$ & $\mathbf{6} \mathbf{~ m i l}$ & $\begin{array}{c}\text { TOTAL } \\
\text { DEMIS }\end{array}$ \\
\hline A1 & 90.99 & 97.59 & 99.26 & 99.66 & 6894 \\
\hline A2 & 97.54 & 98.90 & 99.27 & 99.24 & 2722 \\
\hline A3 & 97.59 & 98.72 & 99.12 & 99.32 & 2832 \\
\hline A TOTAL & $\mathbf{9 5 . 3}$ & $\mathbf{9 8 . 3 8}$ & $\mathbf{9 9 . 2 2}$ & $\mathbf{9 9 . 4 1}$ & $\mathbf{4 1 6 8}$ \\
\hline C1 & 85.43 & 96.08 & 98.01 & 98.78 & 12237 \\
\hline C2 & 96.31 & 98.36 & 99.15 & 99.18 & 3788 \\
\hline C3 & 96.82 & 98.58 & 98.89 & 99.23 & 3497 \\
\hline C TOTAL & $\mathbf{9 2 . 7 3}$ & $\mathbf{9 7 . 6 5}$ & $\mathbf{9 8 . 6 7}$ & $\mathbf{9 9 . 0 6}$ & $\mathbf{6 5 0 8}$ \\
\hline
\end{tabular}

Results of etcher qualification:

- The NCMS conductor analysis electrical testing can be used to evaluate process capability very easily. Data can be received and analyzed very quickly.

- The electrical test data clearly displays direct comparisons of process results for decision making.

Accomplishments of etcher qualification:

- Atotech etcher released for production. 


\section{Final Process Benchmarking Comparison}

Each NCMS Imaging Team member was requested to process panels at their new baseline to compare with the original baseline. Tables 11 and 12 show the data from this electrical testing done on 18 by 24 inch panels processed with 4615 and 9015 dry film photoresist, with artwork UMP 3-6. Conductor Analysis Technologies Inc. performed the testing. This data, when compared with the data from Table 1 (the data from the original baseline), shows improvement in yield and reduction in DEMIS.

Table 11. Conductor Yield vs. Nominal

Conductor Width, TM1 and TM2

Sides, DuPont 4615, Alkaline

Etched on 2/96, Tested by

Conductor Analysis Technologies Inc.

\begin{tabular}{|c|c|c|}
\hline $\begin{array}{c}\text { Artwork } \\
\text { Feature } \\
\text { Size (mils) }\end{array}$ & $\begin{array}{c}\text { Conductor } \\
\text { Yield (\%) }\end{array}$ & DEMIS \\
\hline 3 & 99.40 & 321 \\
\hline 4 & 99.68 & 171 \\
\hline 5 & 99.82 & 96 \\
\hline 6 & 99.82 & 96 \\
\hline
\end{tabular}

DEMIS = Defects per Million Inches of Conductor

Table 12. Conductor Yield vs. Nominal Conductor Width, TM1 and TM2

Sides, DuPont 9015, Alkaline Etched on 2/96, Tested by Conductor Analysis Technologies Inc.

\begin{tabular}{|c|c|c|}
\hline $\begin{array}{c}\text { Artwork } \\
\text { Feature } \\
\text { Size (mils) }\end{array}$ & $\begin{array}{c}\text { Conductor } \\
\text { Yield (\%) }\end{array}$ & DEMIS \\
\hline 3 & 94.65 & 2915 \\
\hline 4 & 98.79 & 649 \\
\hline 5 & 99.03 & 526 \\
\hline 6 & 99.79 & 116 \\
\hline
\end{tabular}

DEMIS $=$ Defects per Million Inches of Conductor 
Tables 13 and 14 show the data from this electrical testing done on 18 by 24 inch panels processed with 4615 and 9015 dry film photoresist, with artwork MP 2-12. Texas Instruments, Austin TX, performed the testing. This data, when compared with the data from Table 2 and 3 (the data from the original baseline), shows improvement in yield and reduction in DEMIS.

Results of 3-6 final benchmarking:

- All conductor widths yielded better than $90 \%$ using the UMP 3-6 artwork.

Accomplishments of 3-6 final benchmarking:

- FM\&T does show improvement in resolving of 5 and 6 mil lines and spaces. This is shown by comparing Table 1 (original baseline) to Table 11 (February 1996 processed). Table 15 in the accomplishments of this report also contains this comparison.

Table 13. Conductor Yield vs. Nominal Conductor Width, TM1 and TM2 Sides, DuPont 4615 Photoresist, Etched 2/96, Tested by Texas Instruments

\begin{tabular}{|c|c|c|}
\hline $\begin{array}{c}\text { Artwork } \\
\text { Feature } \\
\text { Size (mils) }\end{array}$ & $\begin{array}{c}\text { Conductor } \\
\text { Yield (\%) }\end{array}$ & DEMIS \\
\hline 2 & 0.00 & ---- \\
\hline 3 & 0.00 & ---- \\
\hline 4 & 0.62 & 62448 \\
\hline 5 & 15.00 & 23300 \\
\hline 6 & 46.25 & 9456 \\
\hline 7 & 66.88 & 4926 \\
\hline 8 & 74.38 & 3620 \\
\hline 9 & 83.12 & 2257 \\
\hline 10 & 90.00 & 1285 \\
\hline 11 & 90.00 & 1284 \\
\hline 12 & 96.88 & 387 \\
\hline
\end{tabular}

DEMIS $=$ Defects per Million Inches of Conductor 
Table 14. Conductor Yield vs. Nominal Conductor Width, TM1 and TM2 Sides, DuPont 9015 Photoresist, Etched 2/96, Tested by Texas Instruments

\begin{tabular}{|c|c|c|}
\hline $\begin{array}{c}\text { Artwork } \\
\text { Feature } \\
\text { Size } \\
\text { (mils) }\end{array}$ & $\begin{array}{c}\text { Conductor } \\
\text { Yield (\%) }\end{array}$ & DEMIS \\
\hline 2 & 0.00 & ---- \\
\hline 3 & 0.00 & ---- \\
\hline 4 & 1.25 & 53919 \\
\hline 5 & 17.08 & 21703 \\
\hline 6 & 38.33 & 11758 \\
\hline 7 & 55.00 & 7319 \\
\hline 8 & 72.50 & 3932 \\
\hline 9 & 82.50 & 2349 \\
\hline 10 & 86.25 & 1804 \\
\hline 11 & 88.75 & 1455 \\
\hline 12 & 94.58 & 678 \\
\hline
\end{tabular}

DEMIS $=$ Defects per Million Inches of Conductor

Results of final 2-12 benchmarking:

- FM\&T has no 2 or 3 mil data using the MP 2-12 artwork.

- Shorts were the biggest defect throughout the panels.

- This data demonstrates a problem of under-develop or under-etch.

Accomplishments of final $2-12$ benchmarking:

- FM\&T did establish a baseline for conductor analysis testing.

- FM\&T did not demonstrate in these February 1996 panels an improvement in the resolution of 2, 3, and 4 mil lines and spaces using the MP 2-12 artwork. FM\&T has accomplished a baseline for future improvement, and with the procurement of an in-house tester, future process improvement will be accomplished. This is shown by comparing Tables 3 and 4 (original baseline) to Tables 15 and 16 (February 1996 processed). Table 16 in the Accomplishments section of this report also contains this comparison. 


\section{ACCOMPLISHMENTS}

The accomplishments of the NCMS involvement can be summarized in the following four categories:

1. Baselining

FM\&T imaging capability was baselined.

Real-time improvement can be seen in Table 15, where the results of panels processed in 1994 are compared to panels processed in 1996 using the uniformity multipitch pattern and tested by Conductor Analysis Technologies Inc.

Table 15. Uniformity Multipitch Pattern Results

\begin{tabular}{|c|c|c|c|c|}
\hline & $\begin{array}{c}\mathbf{5} \text { mil } \\
\text { YIELD }\end{array}$ & $\begin{array}{c}\mathbf{5} \text { mil } \\
\text { DEMIS }\end{array}$ & $\begin{array}{c}\mathbf{6} \text { mil } \\
\text { YIELD }\end{array}$ & $\begin{array}{c}\mathbf{6} \text { mil } \\
\text { DEMIS }\end{array}$ \\
\hline 1994 & 95.06 & 4066 & 94.94 & 4218 \\
\hline 1996 & 99.40 & 321 & 99.68 & 171 \\
\hline
\end{tabular}

No noticeable improvement can be seen in Table 16, where the results of panels processed in 1994 are compared to panels processed in 1996 using the multipitch 2-12 pattern and tested by Texas Instruments, Austin, TX.

Table 16. Multipitch 2-12 Pattern Results

\begin{tabular}{|c|c|c|c|c|c|c|c|c|}
\hline & $\begin{array}{c}\mathbf{2} \mathbf{m i l} \\
\text { YIELD }\end{array}$ & $\begin{array}{c}\mathbf{2} \mathbf{m i l} \\
\text { DEMIS }\end{array}$ & $\begin{array}{c}\mathbf{3} \mathrm{mil} \\
\text { YIELD }\end{array}$ & $\begin{array}{c}\mathbf{3} \mathbf{m i l} \\
\text { DEMIS }\end{array}$ & $\begin{array}{c}\mathbf{4} \mathbf{m i l} \\
\text { YIELD }\end{array}$ & $\begin{array}{c}\mathbf{4} \mathrm{mil} \\
\text { DEMIS }\end{array}$ & $\begin{array}{c}\mathbf{5} \mathbf{m i l} \\
\text { YIELD }\end{array}$ & $\begin{array}{c}\mathbf{5} \mathbf{m i l} \\
\text { DEMIS }\end{array}$ \\
\hline $\mathbf{1 9 9 4}$ & 0.00 & -- & 0.00 & -- & 16.50 & 22171 & 57.50 & 6797 \\
\hline $\mathbf{1 9 9 6}$ & 0.00 & -- & 0.00 & - & 0.62 & 62448 & 15.00 & 23300 \\
\hline
\end{tabular}

\section{Process Qualification}

The conductor analysis electrical testing method was used to evaluate and qualifiy a new dry film photoresist and qualify a new alkaline etch system, reducing both time and expense.

Prior to the availability of this tool, the patterns were measured manually; numerous cross sections and SEM photographs were required to completely qualifiy imaging materials and equipment. By using the conductor analysis electrical testing method, labor was reduced by approximately $80 \%$.

Qualification time was estimated to have been reduced by $50 \%$. 


\section{Continuous Improvement Assessment}

Based on the labor and qualification time reduction experienced with conductor analysis electrical testing, FM\&T ordered electrical test equipment from CAT Inc. for process verification, characterization, and qualification. The tester was delivered and made operational in June, 1996.

\section{FM\&T Process and Equipment Improvements During NCMS Involvement}

a. Hot Roll Laminate -- increased temperature of hot roll laminator to optimize parameters for DuPont Dry Film 9015 and DuPont 4615.

b. Expose -- increased vacuum pull down time for 18 by 24 inch panels.

c. Develop - reduced conveyor speed to resolve two mil line and spaces on 18 by 24 inch panels. Current 12 by 12 inch production used a conveyor speed of $2.5 \mathrm{fpm}$; however, for 18 by 24 inch panels, a speed of $2.25 \mathrm{fpm}$ resulted in higher yields.

d. Etch Equipment -- qualification of new etcher using the conductor analysis electrical testing reduced the qualification flowtime and associated expenses. 


\section{BIBLIOGRAPHY}

1. S. E. Goldammer, Characterization of DuPont 9015 Aqueous Processable Dry Film Photoresist for Printed Wiring Boards, FM\&T: KCP-613-5537. April 1995 (available from NTIS).

2. R. A. Carhart, L. O. Connally, and A. J. Murray, Process Improvements for Fine Line Conductor Formation. Proceedings of the IPC Technical Conference, March 1996, San Jose, CA.

3. R. D. Rust, NCMS PWB Interconnect System Imaging Component Three Year Report, April 1991 to April 1994. 


\section{APPENDIX}

\section{FM\&T Print and Etch Processing Sequence and Parameters Used for Etch Equipment Qualification}

1. WET BLAST -- horizontally conveyorized CE\#66334, ICM Vapor Blast Liquid Honing Machine, Silicon Dioxide Abrasive

2. CHEMICAL CLEAN -- same as operation 1.

Table A-1. Wet Blast and Chemical Clean

\begin{tabular}{|l|l|l|l|l|l|}
\hline $\begin{array}{l}\text { Process } \\
\text { Sequence }\end{array}$ & $\begin{array}{l}\text { Material } \\
\text { Name }\end{array}$ & $\begin{array}{l}\text { Concen- } \\
\text { tration }\end{array}$ & $\begin{array}{l}\text { Temper- } \\
\text { ature }\end{array}$ & $\begin{array}{l}\text { Dwell } \\
\text { Time }\end{array}$ & $\begin{array}{l}\text { Belt } \\
\text { Speed }\end{array}$ \\
\hline Alkaline Clean & $\begin{array}{l}\text { MacDermid } \\
\text { Metex P-507 }\end{array}$ & $19 \mathrm{~g} / \mathrm{L}$ & $\begin{array}{l}140^{\circ} \mathrm{F} \\
(135- \\
145)\end{array}$ & $42 \mathrm{sec}$. & $42 \mathrm{ipm}$ \\
\hline Water Rinse & DI Water & & & & \\
\hline Micro-Etch & $\begin{array}{l}\text { Sodium } \\
\text { Persulfate }\end{array}$ & $\begin{array}{l}60-150 \\
\mathrm{~g} / \mathrm{L}\end{array}$ & Ambient & $30 \mathrm{sec}$. & \\
\hline & Sulfuric Acid & $\begin{array}{l}10-15 \\
\mathrm{~mL} / \mathrm{L}\end{array}$ & & & \\
\hline Water Rinse & DI Water & & & & \\
\hline Dry & Warm Air Dry & & & 30 sec. & \\
\hline
\end{tabular}

3. LAMINATE RESIST -- HOT ROLL LAMINATOR

Table A-2. Laminate Resist

\begin{tabular}{|l|l|l|}
\hline Resist Type & DuPont's 4615 & DuPont's 9015 \\
\hline Set temperature & $110^{\circ} \mathrm{C}$ & $110^{\circ} \mathrm{C}$ \\
\hline Board exit temp & $145^{\circ} \mathrm{F}$ & $145^{\circ} \mathrm{F}$ \\
\hline Speed & 0.8 meters/minute & 0.8 meters/minute \\
\hline $\begin{array}{l}\text { Pressure, air assist for } \\
\text { rollers }\end{array}$ & $27 \mathrm{psi}$ & $27 \mathrm{psi}$ \\
\hline
\end{tabular}




\section{EXPOSE}

Table A-3. Exposure

\begin{tabular}{|l|l|l|}
\hline Step tablet reading & $\begin{array}{l}\text { Stouffer step } \\
\text { tablet } 9 \text { top and } \\
\text { bottom }\end{array}$ & $\begin{array}{l}\text { Stouffer step } \\
\text { tablet } 9 \text { top and } \\
\text { bottom }\end{array}$ \\
\hline Exposure setting & 90 millijoules $/ \mathrm{cm}^{2}$ & 90 millijoules $/ \mathrm{cm}^{2}$ \\
\hline Exposure time & 12.6 seconds & 12.8 seconds \\
\hline
\end{tabular}

\section{THERMAL BUMP}

Etcher Evaluation only (hot roll laminator with no photoresist -- Day 2 and Day 3 panels only).

Table A-4. Thermal Bump

\begin{tabular}{|l|l|}
\hline Date & $8 / 8 / 95$ \\
\hline Set temperature & $100^{\circ} \mathrm{C}$ \\
\hline Board exit temp. & $141-142^{\circ} \mathrm{F}$ \\
\hline Speed & 1.0 meters/minute \\
\hline Pressure & $27 \mathrm{psi}$ \\
\hline
\end{tabular}

\section{DEVELOP}

$1 \%$ by wt. sodium carbonate monohydrate and DI water solution in a horizontally conveyorized spray system.

Table A-5. Developing

\begin{tabular}{|l|l|}
\hline Solution $\mathrm{pH}$ & $10.5-11.5$ \\
\hline Solution temperature & $80^{\circ} \mathrm{F}$ \\
\hline Speed & 2.25 feet/minute \\
\hline Spray pressure & 28 top \& bottom \\
\hline
\end{tabular}




\section{7. $\mathrm{ETCH}$}

Table A-6. Etching (8/8/95)

\begin{tabular}{|l|l|l|l|}
\hline & \multicolumn{1}{|c|}{ Chemcut } & \multicolumn{1}{c|}{ Atotech } & \multicolumn{1}{c|}{ Limits } \\
\hline $\mathrm{pH}$ & 7.80 & 7.70 & $7.6-7.8$ \\
\hline Copper content & 156.80 grams/liter & 160.0 grams/liter & $145-165$ \\
\hline Temperature & $125^{\circ} \mathrm{F}$ & $125^{\circ} \mathrm{F}$ & \\
\hline Chloride & 199.80 grams/liter & 172.70 grams/liter & $177-212$ \\
\hline Conveyor speed & 42 inches/minute & 38 inches/minute & \\
\hline Etch spray pressures & Upper $=12 \mathrm{psi}$ & $\begin{array}{l}\text { Upper input }=12 \\
\text { psi }\end{array}$ & \\
\hline & Lower $=20 \mathrm{psi}$ & $\begin{array}{l}\text { Upper output }=20 \\
\text { psi }\end{array}$ & \\
\hline & $\begin{array}{l}\text { Lower input }=14 \\
\text { psi }\end{array}$ & \\
\hline & $\begin{array}{l}\text { Lower output }=14 \\
\text { psi }\end{array}$ & \\
\hline
\end{tabular}

\section{STRIP PHOTORESIST}

$3 \%$ potassium hydroxide and DI water in conveyorized spray etch system.

\section{Table A-7. Stripping Photoresist}

\begin{tabular}{|l|l|}
\hline Solution $\mathrm{pH}$ & $10.5-14.0$ \\
\hline Solution Concentration & $3 \%(2.7-3.3)$ by wt. \\
\hline Solution Temperature & $135^{\circ} \mathrm{F}(130-140)$ \\
\hline Speed & 1.5 feet/minute \\
\hline Spray Pressure & 28 top $\&$ bottom \\
\hline
\end{tabular}


M97053644

|||||||||||||||||||||||||||||||||||||||

Report Number (14) KCP - …6/3 ․ 5929

subl. Date (11) 199706

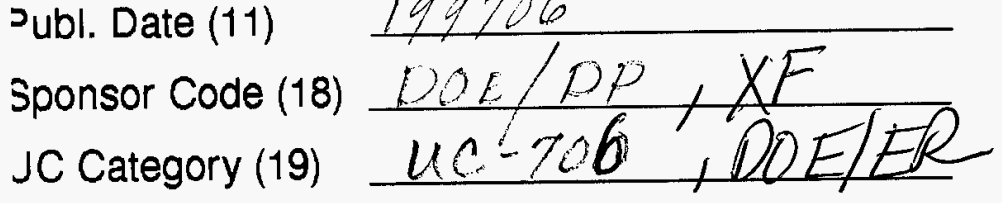

DOE 